\title{
The reduction in proline buildup in mycorrhizal plants affected by nematodes
}

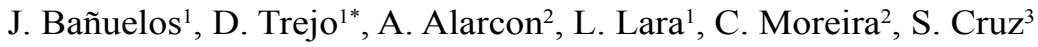 \\ ${ }^{1}$ Universidad Veracruzana Facultad de Ciencias Agrícolas, Laboratorio de Organismos Benéficos. Circuito \\ Gonzalo Aguirre Beltrán s.n. Zona Universitaria Xalapa,Veracruz. CP 91000. México. ${ }^{2}$ Laboratorio de \\ Micorrizas, Área de Microbiología. Especialidad de Edafología. Instituto de Recursos Naturales, Colegio de \\ Postgraduados. Campus Montecillo Km. 36.5. Carretera México-Texcoco. Montecillo, Texcoco, Estado de \\ México.CP 56230. México. ${ }^{3}$ Unidad de Servicios de Apoyo en Resolución Analítica (SARA), Dr. Luis Castelazo \\ Ayala s/n, Col. Industrial-Animas, Xalapa, Veracruz CP 91190, México.
}

*Corresponding author: doratrejo59@hotmail.com

\begin{abstract}
Plants stressed by pathogens activate a variety of defense mechanisms to survive. The osmoprotector amino acids, including proline, are among these defense mechanisms. In this work, the effects of arbuscular mycorrhizal fungi on plants infested by root-knot nematodes were evaluated with regard to the accumulation of the osmoprotectant proline. A $2 \times 3$ factorial design was established with 8 treatments with and without nematodes, with and without mycorrhizae, and with and without fertilizer application - with 4 replicates. Two weeks after inoculation with arbuscular mycorrhizal fungi, the plants were infested with 4 nematode egg masses, and 8 weeks later, the plants were harvested. The inoculation with the arbuscular mycorrhizal fungi significantly reduced the proline content, with the non-inoculated plants exhibiting a higher concentration. Neither the infestation of the nematodes nor the addition of fertilizer significantly affected the proline content. Plant height, stem diameter, leaf area, number of leaves, and fresh weight were significantly improved by the presence of the arbuscular mycorrhizal fungi. The interaction of the fungi and the fertilizer did have a significant effect for height and leaf area. The nematode infestation and the fertilization did not affect mycorrhizal colonization.
\end{abstract}

Keywords: mycorrhizae, proline, Meloidogyne incognita, Impatiens balsamina, stress. 


\section{Introduction}

Arbuscular mycorrhizal fungi (AMF) play a significant role in plant physiology because they increase nutrient uptake and modify plant metabolism, which leads to a reduced response to stress and increased resistance to pathogen attacks (García-Rodriguez et al., 2005; Hause et al., 2007).

Phytoparasitic nematodes and AMF frequently colonize root tissues, and both types of organisms display the same seasonal dynamics; this spatial and temporal coincidence increases the likelihood of interaction (Ingham, 1988). Both organisms affect the host's physiology; however, nematodes cause a pathogenic stress to the plant (Fatemy et al., 1985), whereas AMF may improve stress tolerance (Beltrano and Ronco, 2008).

A number of metabolites and survival defense mechanisms are activated in plants subjected to environmental stresses such as drought, salinity, or pathogen attack (Shulaev et al., 2008). Previous research has revealed that mycorrhizal plants show a higher tolerance to environmental stress (Porcel et al., 2007; Ruiz-Lozano and Azcón, 1995). As a stress response, some substances are synthesized by the plant in response to stress conditions, including osmoprotector amino acids (Hassan et al., 1994) such as proline, which may increase stress tolerance to the plant (Shulaev et al., 2008). Proline content has been shown to vary between mycorrhizal and non-mycorrhizal plants (Ruiz-Lozano and Azcón, 1995; Saglam et al., 2008); thus, proline content may serve as an interesting parameter by which to evaluate the effect of microorganisms on plants.

Given that mycorrhizal symbiosis could represent a mechanism by which stress tolerance is increased in plants. The influence that the fungal symbiosis may have on a plant's defense strategies in response to pathogenic attack may provide more detailed infor- mation related to the mechanisms involved in the interaction among mycorrhizal fungi, the pathogen and the plant stress responses this tripartite interaction.

\section{Materials and methods}

\subsection{Experimental design and statistical analysis}

This experiment included a $2 \times 2 \times 2$ factorial design; each factor included two levels as follows: with/ without nematodes, with/without mycorrhizae (MTZUV consortium), and with/without fertilizer. These conditions resulted in 8 treatments: control (C), with mycorrhizae (M), nematode plus mycorrhizae (MN), fertilizer plus mycorrhizae (MF), mycorrhizae plus nematode plus fertilizer (MNF), nematode $(\mathrm{N})$, nematode plus fertilizer (NF) and fertilizer (F). Each treatment included four replicates. Data were subjected to a factorial analysis of variance (Kavanova et al., 2006) with 8 treatments followed by Fisher's least significant difference (LSD) test.

\subsection{Substrate}

A mixture of soil, sand, red volcanic stone and peat moss $(2: 1: 1: 1 \mathrm{v} / \mathrm{v})$ was sterilized with $0.38 \mathrm{~g} / \mathrm{L}$ dazomet. This mixture was characterized by a $\mathrm{pH}$ of 5.4 (10 g soil in $25 \mathrm{~mL}$ water) and with $\mathrm{N}, \mathrm{P}$ and $\mathrm{K}$ levels of $45.38,5.3$ and $40 \mathrm{mg} \mathrm{kg}^{-1}$, respectively.

\subsection{Nutrient addition}

A nutrient solution including $\mathrm{N}, \mathrm{P}$ and $\mathrm{K}$ was used in the fertilized treatment to achieve levels of $150 \mathrm{mg}$ $\mathrm{kg}^{-1} \mathrm{~N}, 32.23 \mathrm{mg} \mathrm{kg}^{-1} \mathrm{P}$ and $40.67 \mathrm{mg} \mathrm{kg}^{-1} \mathrm{~K}$ (using a triple-17 formulation including $\mathrm{NH}_{4} \mathrm{NO}_{3}, \mathrm{NHPO}_{4}$ and $\mathrm{KNO}_{3}$ as a nutrient source). 


\subsection{Plant selection}

Impatiens balsamina L. was used as model plant because its positive response to AMF inoculation has been previously demonstrated. Additionally, despite being a host of the gall-forming nematode, this plant resists infestations without dying, a tolerance that enables it to complete its life cycle. The roots of this species are scarcely pigmented, enabling AMF and nematode galls to be easily observed.

\subsection{AMF inoculation}

An inoculum (MTZ-UV) was used that consisted of 8 AMF species of the genera Glomus, Acaulospora, Gigaspora and Scutellospora propagated through the modified Sieverding technique (Sieverding, 1991).

\subsection{Nematode inoculum}

Meloidogyne incognita was used for these experiments. The inoculum was obtained from wild $I$. balsamina plants (McSorley and McGovern, 2001). Plants were inoculated with nematode eggs 15 days after AMF inoculation. Four egg masses were applied per sprout into pits in the substrate near the shoot base $(0.5 \mathrm{~cm}$ from the shoot and $1.5 \mathrm{~cm}$ deep) (Sunil et al., 2007). This four egg masses gave approximately 500 juvenile (J2) nematodes, and according to Zahid et al. (2001) that is the minimum number of juveniles for a potential infection

\subsection{The assessment of variables}

Plants were harvested 10 weeks after AMF inoculation. Physical variables and mycorrhizal colonization were recorded. Proline was measured in the shoot 2 days after harvesting using the Bates (1973) technique; this amino acid was not analyzed in roots because the presence of nematodes and fungi may affect proline concentrations (Verbruggen et al., 1993).

\section{Results}

The effects on growth promoted by inoculation with the MTZ-UV consortium were evident 30 days after AMF inoculation (Table 1), with colonization ranging between $25 \%$ and $65 \%$. All I. balsamina plants infested with $M$. incognita exhibited galls in the root system. However, only those with no mycorrhizae showed noticeable symptoms of disease, including wilting, leaf yellowing, severe root damage and the presence of galls; in contrast, non-infested plants displayed no symptoms of disease (Table 1).

Table 1. The mean values of the measured parameters in Impatiens balsamina plants inoculated with Meloidogyne incognita $(\mathrm{N})$, AM fungus $(\mathrm{M})$ and fertilization $(\mathrm{F})$ as the main factors and their interactions.

\begin{tabular}{lcccccccc}
\hline Variable & $\mathbf{C}$ & $\mathbf{F}$ & $\mathbf{N}$ & $\mathbf{N F}$ & $\mathbf{M}$ & $\mathbf{M F}$ & $\mathbf{M N}$ & MNF \\
\hline Leaf area $\left(\mathrm{cm}^{2}\right)$ & $0.6 \mathrm{c}$ & $0.46 \mathrm{c}$ & $0.56 \mathrm{c}$ & $0.43 \mathrm{c}$ & $13.04 \mathrm{~b}$ & $27.51 \mathrm{a}$ & $9.2 \mathrm{~b}$ & $25.88 \mathrm{a}$ \\
Leaf number & $3.25 \mathrm{~d}$ & $3.33 \mathrm{~d}$ & $2.33 \mathrm{~d}$ & $2.33 \mathrm{~d}$ & $6.67 \mathrm{c}$ & $12.0 \mathrm{~b}$ & $7.0 \mathrm{c}$ & $16.0 \mathrm{a}$ \\
Leaf fresh weight $(\mathrm{g})$ & $0.04 \mathrm{~d}$ & $0.07 \mathrm{~d}$ & $0.04 \mathrm{c}$ & $0.04 \mathrm{~d}$ & $0.67 \mathrm{c}$ & $1.03 \mathrm{~b}$ & $0.46 \mathrm{c}$ & $1.53 \mathrm{a}$ \\
Height $(\mathrm{cm})$ & $1.16 \mathrm{c}$ & $1.56 \mathrm{c}$ & $1.23 \mathrm{c}$ & $1.26 \mathrm{c}$ & $2.96 \mathrm{~b}$ & $5.56 \mathrm{a}$ & $2.43 \mathrm{~b}$ & $5.33 \mathrm{a}$ \\
Diameter $(\mathrm{cm})$ & $1.2 \mathrm{~d}$ & $1.4 \mathrm{~cd}$ & $1.5 \mathrm{~d}$ & $1.49 \mathrm{~d}$ & $2.8 \mathrm{~b}$ & $2.75 \mathrm{~b}$ & $2.03 \mathrm{c}$ & $3.4 \mathrm{a}$ \\
AM fungal colonization & - & - & - & - & $49.4 \mathrm{~b}$ & $24.47 \mathrm{~d}$ & $38.19 \mathrm{c}$ & $66.31 \mathrm{a}$ \\
Proline $\left(\mu \mathrm{g} \mathrm{mL}^{-1}\right)$ & $3.42 \mathrm{a}$ & $2.21 \mathrm{ab}$ & $3.59 \mathrm{a}$ & $2.19 \mathrm{ab}$ & $0.69 \mathrm{~b}$ & $1.15 \mathrm{~b}$ & $0.72 \mathrm{~b}$ & $0.69 \mathrm{~b}$ \\
\hline
\end{tabular}

Different letters denote significant differences of a multiple-range test. Treatments without AMF were not included in the analysis of variance. $\mathrm{C}=\mathrm{Control}$ plants. 


\subsection{The response of growth variables}

The AMF had a significant effect on all the variables measured (Table 2). Inoculation with the nematodes did not lead to any significant differences in growth variables (Table 2). With regard to the interaction between factors, the MN and NF treatments caused no noticeable differences in growth variables (Table 2).
The presence of the nematodes affected only the root colonization percentage (Table 2). The addition of the fertilizer had a significant effect on all the variables except for the diameter (Table 2). The proline content was significantly affected by the $\mathrm{M}$ treatment, whereas neither the fertilizer nor the presence of nematodes affected the proline content. The interaction of $\mathrm{M}$ and $\mathrm{F}$ had a significant effect on the variable.

Table 2. The probability $(\mathrm{P})$ values from analyses of variance of the measured parameters in Impatiens balsamina plants inoculated with Meloidoyne incognita (N), AM fungus (M) and fertilization (F) as the main factors and their interactions.

\begin{tabular}{lccccccc}
\hline Variable & $\mathbf{M}$ & $\mathbf{N}$ & $\mathbf{F}$ & $\mathbf{N F}$ & $\mathbf{M N}$ & $\mathbf{M F}$ & $\mathbf{M N F}$ \\
\hline Leaf area $\left(\mathrm{cm}^{2}\right)$ & $* * *$ & $\mathrm{NS}$ & $* * *$ & $\mathrm{NS}$ & $\mathrm{NS}$ & $* * *$ & $* * *$ \\
Leaf number & $* * *$ & $\mathrm{NS}$ & $* * *$ & $\mathrm{NS}$ & $\mathrm{NS}$ & $* * *$ & $* * *$ \\
Leaf fresh weight $(\mathrm{g})$ & $* * *$ & $\mathrm{NS}$ & $* * *$ & $\mathrm{NS}$ & $\mathrm{NS}$ & $* *$ & $* * *$ \\
Height $(\mathrm{cm})$ & $* * *$ & $\mathrm{NS}$ & $* * *$ & $\mathrm{NS}$ & $\mathrm{NS}$ & $* * *$ & $* * *$ \\
Diameter $(\mathrm{cm})$ & $* * *$ & $\mathrm{NS}$ & $* * *$ & $\mathrm{NS}$ & $\mathrm{NS}$ & $\mathrm{NS}$ & $* * *$ \\
AM fungus colonization & - & - & - & - & $* *$ & $* * *$ & $* *$ \\
Proline $\left(\mu \mathrm{gL}^{-1}\right)$ & $* * *$ & $\mathrm{NS}$ & $\mathrm{NS}$ & $\mathrm{NS}$ & $\mathrm{NS}$ & $* *$ & $\mathrm{NS}$ \\
\hline
\end{tabular}

$*: \mathrm{P}<0.05 ; * *: \mathrm{P}<0.01 ; * * *: \mathrm{P}<0.001$. Treatments without AMF were not included in the analysis of variance.

AMF: arbuscular mycorrhizal fungi; NS: no significance.

\section{Discussion}

AMF inoculation improves plant development, as shown in several reports in which a great variety of species have responded favorably to mycorrhizae (Jaizme-Vega and Rodríguez-Romero, 2004; Talavera et al., 2001).

In the present investigation, mycorrhizal inoculation resulted in an increase in plant tolerance to nematode attacks in agreement with the findings of other reports (Talavera et al., 2001). Plants inoculated with AMF displayed good development and, hence, were more resistant to that stress because vascular cylinders are clogged and the root area decreases in plants infested by nematodes (Agrios, 1989). AMF provide ben- efits to the plant, likely through root hydration mechanisms strengthened or mediated by fungal hyphae (Hardie, 1985; Marulanda et al., 2003; Ruiz-Lozano and Azcón, 1995), facilitating mineral nutrient absorption (Varma, 1995) or through morphological changes in roots caused by AMF (Kothari et al., 1990). Such effects of mycorrhizae enable plants to maintain a better hydration and nutrition status at all times, even in the presence of the parasite (Augé, 2001). This result demonstrates the ability of AMF to offset the effects of nematodes when a certain mycorrhizal inoculation level is reached. Saleh and Sikora (1984) demonstrated that to achieve some degree of pathogen control, the mycorrhizal colonization of $38 \%$ of the root system is required, although this percentage may vary 
depending on the host species, the symbiont species and other biotic and abiotic conditions. The percent colonization observed in the present work (Table 1) was higher than those reported by Saleh and Sikora (1984); hence, the level of colonization here can be deemed sufficient to offset the damage caused by the pathogen. Although AMF-inoculated plants displayed galls, these showed no signs of damage in the shoot.

This investigation assessed biochemical aspects on plant tolerance to a pathogen as a result of AMF inoculation. Mycorrhized plants displayed a rise in biomass production (586\%) over the course of 50 days following nematode inoculation. However, Melakeberhan and Webster (1993) note that biomass loss due to nematode delete depends on the infestation level, larval stage, reproductive potential and duration of the infestation.

In this study, a considerable reduction in proline content was observed in AMF-inoculated plants. Similar results have been reported in the case of water stress, with mycorrhizal plants showing lower proline levels in the shoot (Ruiz-Lozano and Azcón, 1995; Saglam et al., 2008). Although the stress derived from nematode attacks involves mechanisms that differ from those associated with water deficit, since plant vascular cylinders are clogged when nematodes infest the root (Agrios, 1989), thereby altering root functioning and reducing water uptake, which leads to water stress and nutrient deficit.

Although proline is accumulated in stressed plants, it is normally present at certain levels (Grote $e t$ al., 2006; Masadeh, 2005), either because of a nutrient deficit, light intensity, shifts in temperature, salinity, anaerobioses, air pollution or UV radiation (Deuschle et al., 2004; Hare and Cress, 1997).

The decrease in proline content in mycorrhizal plants, even in the presence of the pathogen, may be related to the mycorrhizal function of exerting a qualitative and quantitative influence on flavonoid content and metabolism (Harrison and Dixon, 1993), thereby reducing proline synthesis and use, although this parameter was not measured. Plants inoculated with the AMF displayed a lower concentration of proline, which may indicate a lower stress level in the plant under normal conditions, as observed by Hare and Cress (1997). This lower stress stage may be related to a better nutritional status (Cantrell and Linderman, 2001).

The findings reported here may indicate that the presence of inorganic nutrients without mycorrhizae failed to produce better results in terms of growth variables as reported previously (Endlweber and Scheu, 2006; Rodríguez-Romero et al., 2005). An increase in nutrient intake by the plant is likely when it is colonized by AMF, even in the presence of the nematode, a condition that results in an impared root system. The proper development of plants in this experiment suggests that the mycorrhizae promoted an adequate nutrient intake, given that AMF-inoculated plants grew even under nematode infestation.

Impatiens balsamina is a highly mycotrophic species. Because its roots are scarcely pigmented, they are readily stained, enabling AMF structures to be easily observed. Additionally, the tolerance of this plant to gall-nematode attacks, its rapid growth and high reproductive effort jointly suggest a high capacity to withstand stress (because it survives in heavily disturbed environments). Therefore, this species represents an attractive model for investigating nematode-mycorrhiza interactions.

Impatiens balsamina has been proposed by McAbee et al. (2005) as a suitable species for studying the diversification in the integument morphology within the genus Impatiens. Furthermore, this species has been used as a model for assessing the flowering process and floral reversion (Battley and Lyndon, 1986, 1988, 1990; Pouteau et al., 1995, 1997, 1998), all of which support the suitability of this species for a number of studies. 


\section{Conclusions}

Overall, the mycorrhizal plants improved the growth variables, despite the presence of nematodes, when the fertilizer was present. Mycorrhizal plants produced less proline. In contrast, the concentration of the proline the amino acid increased in plants infested by nematodes. These results support the hypothesis that mycorrhizae contribute to both the nutrition, expressed in growth, and the production of secondary compounds, associated with the decreased effect of the pathogen. Impatiens balsamina was successfully used as a model plant to study the interaction between AMF and nematodes because it exhibited a good response to the mycorrhizal effect in 20-30 days; a short life cycle; low pigmentation in the roots, which aids in observing the microorganisms; and the ability to tolerate nematode infestation enough to complete its life cycle.

\section{References}

Agrios, G. N. 1989. Fitopatología. II ed. Limusa, México D.F.743.

Augé, R. M. 2001. Water relations, drought and vesicular-arbuscular mycorrhizal symbiosis. Mycorrhiza 11:3-42.

Bates, L. S. 1973. Rapid determination of free proline for water stress studies. Plant Soil, 39:205-207.

Battley, N. H., Lyndon, R. F. 1986. Apical growth and modification of the development of primordia during re-flowering of reverted plants of Impatiens balsamina L. Annals of Botany, 58:333-341.

Battley, N. H., Lyndon, R. F. 1988. Determination and differentiation of leaf and petal primordia in Impatiens balsamina. Annals of Botany, 61:9-16.

Battley, N. H., Lyndon, R. F. 1990. Reversion of flowering. Botanical Review, 56:162-189.
Beltrano, J., Ronco, M. G. 2008. Improved tolerance of wheat plants (Triticum aestivum L.) to drought stress and rewatering by the arbuscular mycorrhizal fungus Glomus claroideum: Effect on growth and cell membrane stability. Brazilian Journal of Plant Physiology, 20:29-37.

Bouamri, R., Dalpé, Y., Serrhini, M. N., Bennani, A. 2006. Arbuscular mycorrhizal fungi species associated with rhizosphere of Phoenix dactylifera L. in Morocco. African Journal of Biotechnology, 5:510-516.

Cantrell, I. C., Linderman, R. G. 2001. Preinoculation of lettuce and onion with mycorrhizal fungi reduces deleterious effects of soil salinity. Plant Soil, 233:269-281.

Deuschle, K., Funck, D., Forlani, G., Stransky, H., Biehl, A., Leister, D., van der Graaff, E., Kunze, R., Frommer, W. B. 2004. The role of Delta 1-pyrroline-5-carboxylate dehydrogenase in proline degradation. Plant Cell and Environment, 16:3413-3425.

Endlweber, K., Scheu, S. 2006. Effects of Collembola on root properties of two competing ruderal plant species. Soil Biology \& Biochemistry, 38:20252031.

Fatemy, Y., Trinder, K. E., Wisgfield, J. N., Evans, K. 1985. Effects of Globodera rostochiensis, water stress and exogenous abscisic acid on stomatal function and wateurse of Cara and Pentland Dell potato plants Revue Nématol.,8 :. Revue Nématology, 8:249-255.

García-Rodriguez, S., Pozo, M. J., Azcón-Aguilar, C., Ferrol, N. 2005. Expression of a tomato sugar transporter is increased in leaves of mycorrhizal or Phytophthora parasitica infected plants Mycorrhiza. Mycorrhiza, 15:489-496.

Grote, D., Schmidt, R., Claussen, W. 2006. Water uptake and praline index as indicators of predisposition in tomato plants to Phytophtora nicotianae 
infection as influenced by abiotic stresses. Physiological and Molecular Plant Pathology 69:121130.

Hardie, K. 1985. The effect of removal of extraradical hyphae on water uptake by vesicular-arbuscular mycorrhiza on growth and water relations of red clover. I. In phosphate deficient soil. New Phytologist, 101:677-684.

Hare, P. D., Cress, W. A. 1997. Metabolic implications of stress-induced proline accumulation in plants. Plant Growth Regulation, 21:79-102.

Harrison, M. J., Dixon, R. A. 1993. Isoflavonoid accumulation and expression of defense gene transcripts during the establishment of vesiculararbuscular mycorrhizal associations in roots of Medicago truncatula. Molecular Plant Microbe Interactions, 6:643-654.

Hassan, H., Khalf-Allah, A. M., Ibrahim, I. K. A., Badr, H. M. 1994. Free amonoacids and oxidative enzymes in infested roots of tomato genotypes resistant and susceptible to Meloidogyne incognita. Nematología Mediterránea, 22:179-183.

Hause, B., Mrosk, C., Isayenkov, S., Strack, D. 2007. Jasmonates in arbuscular mycorrhizal interactions. Phytochemistry, 68:101-110.

Ingham, R. 1988. Interactions between nematodes and vesicular-arbuscular mycorrhizae. Agriculture, Ecosystems and Environment, 24:169-182.

Jaizme-Vega, M. C., Rodríguez-Romero, A. 2004. Uso de micorrizas en banano: Logros y perspectivas. XVI Reunión Internacional ACORBAT 2004, pp. 143-160, España.

Kavanova, M., Grimaldi, A. A., Lattanzi, F. A., Schnyder, H. 2006. Phosphorus nutrition and mycorrhiza effects on grass leaf growth. P status-and size-mediated effects on growth zone kinematics. Plant Cell and Environment, 29:511-520.
Kothari, S. K., Marschner, H., Römheld, V. 1990. Direct and indirect effects of VA mycorrhizal fungi and rhizosphere microorganisms on acquisition of mineral nutrients by maize (Zea mays L.) in a calcareous soil. New Phytologist, 116:637-645.

Marulanda, A., Azcón, R., Ruiz-Lozano, J. M. 2003. Contribution of six arbuscular mycorrhizal fungal isolates to water uptake by Lactuca sativa plants under drought stress. Physiologia Plantarum, 119:526-533.

Masadeh, B. 2005. Bio-Management of Meloidogyne incognita (Tylenchida: Meloidogynidae) on tomato using arbuscular mycorrhizal fungi and rhizobacteria. PhD Thesis., Universität Hannover.

McAbee, J. M., Kuzoff, R. K., Gasser, C. S. 2005. Mechanisms of derived unitegmy among Impatiens species. The Plant Cell, 17:1674-1684.

McSorley, R., McGovern, R. J. 2001. Effect of rhizobacteria on nematodes associated with Impatiens. Soil and Crop Science Society of Florida, Vol. 60, pp. 128-131.

Melakeberhan, H., Webster, J. M. 1993. The phenology of plant-nematode interaction and yield loss. In: M. M. Khan (ed.). Nematode Interactions, Chapman and Hall, London, UK. pp. 26-41.

Porcel, R., Aroca, R., Cano, C., Bago, A., Ruiz-Lozano, J. M. 2007. A gene from the arbuscular mycorrhizal fungus Glomus intraradices encoding a binding protein is up-regulated by drought stress in some mycorrhizal plants. Environmental and Experimental Botany, 60:251-256.

Pouteau, S., Nicholls, D., Tooke, F., Coen, E., Battey, N. 1995. Expression of homeotic genes during induction and reversion of flowering in Impatiens. Flowering Newslett, 19:31-35.

Pouteau, S., Nicholls, D., Tooke, F., Coen, E., Battey, N. 1998. Transcription pattern of a FIM homo- 
logue in Impatiens during floral development and reversion. Plant Journal, 14:235-246.

Pouteau, S., Nicholls, F., Tooke, F., Coen, E., Battey, N. 1997. The induction and maintenance of flowering in Impatiens. Development, 124:3343-3351.

Rocha, F. S., Saggin, O. J., da Silva, E. M. R., de Lima, W. L. 2006. Cedar seedlings dependency and responsiveness to arbuscular mycorrhizal fungi. Pesquisa Agropecuária Brasileira, 41:77-84.

Rodríguez-Romero, A. S., Piñero-Guerra, M. S., Jaizme-Vega, M. C. 2005. Effect of arbuscular mycorrhizal fungi rhizobacteria on banana growth and nutrition. Agronomy for sustainable development (Agronomie), 25:395-399.

Ruiz-Lozano, J. M., Azcón, R. 1995. Hyphal contribution to water uptake in mycorrhizal plants as affected by the fungal species and water status. Physiologia Plantarum, 95:472-478.

Saglam, A., Kadioglu, A., Terzi, R., Saruhan, N. 2008. Physiological changes in them in post-stress emerging Ctenanthe steosa plants under drought conditions. Russian Journal of Plant Physiology, 55:48-53.

Saleh, H., Sikora, R. A. 1984. Relationship between Glomus fasciculatum root colonization of cotton and its effect on Meloidogyne incognita. Nematologica, 30:230-237.

Schwob, I., Ducher, M., Coudret, A. 1999. Effects of climatic factors on native arbuscular mycorrhizae and Meloidogyne exigua in a Brazilian rubber tree (Hevea brasiliensis) plantation. Plant Pathology, 48:19-25.

Shulaev, V., Cortes, D., Miller, G., Mittler, R. 2008. Metabolomics for plant stress response. Physiology Plant, 132:199-208.
Sieverding, E. 1991. Vesicular-Arbuscular Mycorrhiza Management in Tropical Agrosystems. Deutsche Gesellschaft für Technische Zusammenarbeit (GTZ) GmbH, Eschborn, Germany. 371.

Sunil, K., Khanna, A. S., Chandel, Y. S. 2007. Susceptibility of mushrooms to Aphelenchoides swarupi and Aphelenchus avenae. nematología Mediterránea, 35:205-211.

Talavera, M., Itou, K., Mizukubo, T. 2001. Reduction of nematode damage by root colonization with arbuscular mycorrhiza (Glomus spp.) in tomatoMeloidogyne incognita (Tylenchida, Meloidognidae) and carrot Pratylenchus penetrans (Tylenchida, Pratylenchidae) pathosystems. Applied Entomology and Zoology 36:387-392.

Varma, A. 1995. Ecophysiology and application of arbuscular mycorrhizal fungi in arid soils. In: A. Varma and B. Hock (eds.). Mycorrhiza, SpringerVerlag, Berlin. 734. pp. 734.

Verbruggen, N., Hermans, C. 2008. Proline acumulation in plants: a review. Aminoacids Springer Wein. Laboratoire de Physiologie et de Génétique moléculaire des Plantes, Université Libre de Bruxelles, Campus Plaine, Brussels, Belgium.

Verbruggen, N., Villarroel, R., Van Montagu, M. 1993. Osmoregulation of a pyrroline-5-carboxylate reductase gene in Arabidopsis thaliana. Plant Physiology, 103:771.

Waceke, J. W., Waudo, S. W., Sikora, R. A. 2001. Response of Meloidogyne hapla to mycorrhiza fungi inoculation. African Journal of Science Technology, 2:63-70.

Zahid, M. I., Nobbs, J., Gurr, G. M., Hodda, M., Nikandrow, A., Filkerson, W. J., Nicol, H. I. 2001. Effect of the clover root-knot nematode (Meloidogyne trifoliophila) on growth of white clover. Nematology, 3:437-44 